\title{
Comparing Genetic Diversity in Three Threatened Oaks
}

\author{
Emma Suzuki Spence ${ }^{1, * \mathbb{D}}$, Jeremie B. Fant ${ }^{2} \mathbb{D}$, Oliver Gailing ${ }^{3,4} \mathbb{D}$, M. Patrick Griffith ${ }^{5}$, Kayri Havens ${ }^{2}$, \\ Andrew L. Hipp ${ }^{1}$, , Priyanka Kadav ${ }^{4}$, Andrea Kramer ${ }^{2}$, Patrick Thompson ${ }^{6}$, Raakel Toppila ${ }^{7}$, \\ Murphy Westwood ${ }^{1}$ (D) Jordan Wood ${ }^{2}$, Bethany A. Zumwalde ${ }^{1,8}$ (D) and Sean Hoban ${ }^{1,9, *(D)}$
}

1 The Morton Arboretum, Center for Tree Science, 4100 Illinois 53, Lisle, IL 60532, USA; ahipp@mortonarb.org (A.L.H.); mwestwood@mortonarb.org (M.W.); bzumwalde@ufl.edu (B.A.Z.)

2 Negaunee Institute for Plant Conservation Science and Action, Chicago Botanic Garden, 1000 Lake Cook Road, Glencoe, IL 60022, USA; jfant@chicagobotanic.org (J.B.F.);

khavens@chicagobotanic.org (K.H.); akramer@chicagobotanic.org (A.K.); woodj.2012@gmail.com (J.W.)

3 Forest Genetics and Forest Tree Breeding, University of Göttingen, 37077 Göttingen, Germany; ogailin@gwdg.de

4 College of Forest Resources and Environmental Science, Michigan Technological University, 1400 Townsend Dr, Houghton, MI 49931, USA; pdkadav@mtu.edu

5 Montgomery Botanical Center, 11901 Old Cutler Rd, Coral Gables, FL 33156, USA; patrick@montgomerybotanical.org

6 Department of Biological Sciences, Auburn University Davis Arboretum, Auburn, AL 36849, USA; thomppg@auburn.edu

7 Longwood Graduate Program in Public Horticulture, University of Delaware, 181 South College Avenue, Newark, DE 19717-5267, USA; raakelt@gmail.com

8 Department of Biology, University of Florida, Gainesville, FL 32611, USA

check for updates

Citation: Spence, E.S.; Fant, J.B.; Gailing, O.; Griffith, M.P.; Havens, K.; Hipp, A.L.; Kadav, P.; Kramer, A.; Thompson, P.; Toppila, R.; et al. Comparing Genetic Diversity in Three Threatened Oaks. Forests 2021, 12, 561. https://doi.org/10.3390/ f12050561

Academic Editors: Mary Ashley and Janet R. Backs

Received: 15 March 2021

Accepted: 19 April 2021

Published: 29 April 2021

Publisher's Note: MDPI stays neutral with regard to jurisdictional claims in published maps and institutional affiliations.

Copyright: (C) 2021 by the authors. Licensee MDPI, Basel, Switzerland. This article is an open access article distributed under the terms and conditions of the Creative Commons Attribution (CC BY) license (https:/ / creativecommons.org/licenses/by/ $4.0 /)$.
9 The Field Museum Chicago, DNA Discovery Center, 1400 S. Lake Shore Dr, Chicago, IL 60605, USA

* Correspondence: spence.suzuki@gmail.com (E.S.S.); shoban@mortonarb.org (S.H.)

\begin{abstract}
Genetic diversity is a critical resource for species' survival during times of environmental change. Conserving and sustainably managing genetic diversity requires understanding the distribution and amount of genetic diversity (in situ and ex situ) across multiple species. This paper focuses on three emblematic and IUCN Red List threatened oaks (Quercus, Fagaceae), a highly speciose tree genus that contains numerous rare species and poses challenges for ex situ conservation. We compare the genetic diversity of three rare oak species-Quercus georgiana, Q. oglethorpensis, and Q. boyntonii-to common oaks; investigate the correlation of range size, population size, and the abiotic environment with genetic diversity within and among populations in situ; and test how well genetic diversity preserved in botanic gardens correlates with geographic range size. Our main findings are: (1) these three rare species generally have lower genetic diversity than more abundant oaks; (2) in some cases, small population size and geographic range correlate with genetic diversity and differentiation; and (3) genetic diversity currently protected in botanic gardens is inadequately predicted by geographic range size and number of samples preserved, suggesting non-random sampling of populations for conservation collections. Our results highlight that most populations of these three rare oaks have managed to avoid severe genetic erosion, but their small size will likely necessitate genetic management going forward.
\end{abstract}

Keywords: conservation biology; fragmentation; botanic gardens; EST; inbreeding; heterozygosity; microsatellites; population genetics; ex situ

\section{Introduction}

Genetic diversity is a critical resource for species to adapt to future challenges including pests and diseases, climate change, and other environmental changes. To conserve and sustainably manage genetic diversity, it is important to understand the distribution and amount of genetic diversity present in situ, and to identify the key factors shaping that genetic diversity [1-3]. While genetic diversity has been assessed in hundreds of rare 
species globally, there are few comparative, multispecies studies of the influence of range size, environmental, and demographic variables on genetic diversity in rare species. Previous studies have shown that, on average, species with larger range sizes (and thus, more populations, larger populations, and lower genetic drift) have higher genetic diversity [4-6]. Additionally, small local populations whose effective size $\left(\mathrm{N}_{\mathrm{e}}\right)$ is $<500$ individuals are generally at risk of genetic drift and loss of adaptive potential; and even smaller populations ( $<50$ individuals) experience rapid genetic erosion and inbreeding problems [7]. Additionally, environmental factors may influence genetic diversity at certain loci through selection by climate or habitat $[8,9]$, or may influence genetic diversity genome-wide through drift as population sizes are reduced or fluctuate in size [10].

It is equally important to understand how well genetic diversity is conserved ex situ. The amount of genetic diversity conserved ex situ may be correlated with some of the same factors impacting genetic diversity in situ (e.g., population size and geographic range size). Species with larger geographic ranges may require more plants ex situ to fully safeguard genetic diversity [11,12], but there are few cases empirically testing this [13]. Determining how many plants are needed to conserve genetic diversity is important to meet global, national, and institutional commitments on conservation. For instance, the Convention on Biological Diversity's Global Strategy for Plant Conservation (GSPC) has created guidelines for crops, crop wild relatives, and other economically important species that calls for "at least $75 \%$ of threatened plant species in ex situ collections, preferably in the country of origin", and for "70\% of genetic diversity" to be conserved, by 2020 [14]. The GSPC also stipulates that collections be "accessible, backed up, and genetically representative". Collections that meet these requirements provide insurance against extinction, support in situ conservation (e.g., supplementation or reintroduction), and provide material for conservation-relevant research $[1,15,16]$. Safeguarding exceptional species is especially challenging [17], as they cannot be kept in traditional seed banks but must be kept ex situ in living collections (i.e., of mature individuals rather than seeds). Exceptional species include many common trees such as magnolias, oaks, cycads, and others.

This paper focuses on the tree genus, Quercus (oaks), for which there are currently 112 oak species threatened globally under the International Union for Conservation of Nature (IUCN) threat categories vulnerable, endangered, or critically endangered [18] with 17 of those in the United States [19]. Unfortunately, acorns are generally recalcitrant (they cannot be stored in conventional seed banks [20]) and are challenging for tissue culture and cryopreservation [21], making oaks an exceptional species. Conservation through living collections in botanic gardens and arboreta is currently the principal ex situ conservation option for threatened oak species [22,23].

Oaks have significant ecological [24], economic [25], and cultural [26] importance, while facing increasing conservation threats including habitat loss, invasive species, shifting climates, and pests/pathogens, such as sudden oak death [27]. For example, oaks support huge numbers of other species that depend on them for mast or forage [28], and many oak species are used for timber or non-timber forest products $[29,30]$. Oaks also feature incredible ecological breadth, having diversified into many habitats through adaptations in leaf traits, phenology, habit, water use, and other traits [31,32]. Identifying and quantifying the factors influencing genetic diversity in situ and ex situ is especially important for speciose genera like oaks, that has 450 species estimated worldwide. Characterizing correlates of genetic diversity in a few well-studied species within the oak phylogeny could serve as the foundation for predictive models of the distribution of genetic diversity. Such models should make it possible to manage genetic diversity in a wide range of species, even when data are not available. Discovering the "rules" underlying the distribution of genetic diversity in situ and ex situ can lead to more efficient conservation.

We focus on three threatened oak species that occur in the Southeastern United States, a hotspot for genetic and species richness for plant taxa, including oak species (Figure A1). This region is of particular conservation interest in light of numerous threats including land use change, increasing drought and high temperatures, changing fire regimes, invasive 
species, urban and suburban sprawl, and extreme weather events [27]. Our focal species for this study-Quercus boyntonii Beadle (critically endangered [19]), Q. oglethorpensis W.H. Duncan (endangered [19]), and Q. georgiana M.A. Curtis (endangered [19])—fit all three categories of rare as outlined by Rabinowitz [33]; small range sizes, high habitat specificity, and low abundance (Table A1). Each species has less than 2000 mature individuals remaining, which are distributed in a few fragmented populations, facing the aforementioned threats. All species are considered habitat specialists (Q. boyntonii on sandstone rock outcrops and steep hillsides, Q. georgiana on granite rock outcrops, and Q. oglethorpensis on poorly drained marshlands or creek bottoms, Table 1), but have differing geographic distributions and habitat requirements (Table 1, Figure 1).

Table 1. Overview and comparison of each of the three species in this study showing geographic range, area of occupancy (AOO), extent of occurrence (EOO), number of adults estimated in the wild, and current population trends. Data compiled from IUCN Red List of Threatened Species.

\begin{tabular}{|c|c|c|c|c|c|}
\hline Species & $\begin{array}{l}\text { IUCN Listing; Habitat and } \\
\text { Geographic Range }\end{array}$ & $\begin{array}{l}\mathrm{AOO} \\
\left(\mathbf{k m}^{2}\right)\end{array}$ & $\begin{array}{l}\text { EOO } \\
\left(\mathrm{km}^{2}\right)\end{array}$ & $\begin{array}{l}\text { Number of } \\
\text { Adult Trees }\end{array}$ & $\begin{array}{c}\text { Population } \\
\text { Trend }\end{array}$ \\
\hline $\begin{array}{l}\text { Quercus } \\
\text { boyntonii }\end{array}$ & $\begin{array}{l}\text { Critically Endangered; restricted } \\
\text { occurrence in Alabama, restricted } \\
\text { to sandstone outcrops and glades, } \\
\text { and steep dry hillsides }\end{array}$ & 24 & 4157 & 50-200 & Stable \\
\hline $\begin{array}{l}\text { Quercus } \\
\text { georgiana }\end{array}$ & $\begin{array}{l}\text { Endangered; restricted to isolated } \\
\text { granite outcrops and flat-rocks in } \\
\text { the Piedmont Plateau of the } \\
\text { Southeastern United States. }\end{array}$ & $72-272$ & $16,570-21,600$ & Unknown & Decreasing \\
\hline $\begin{array}{c}\text { Quercus } \\
\text { oglethorpensis }\end{array}$ & $\begin{array}{l}\text { Endangered; disjunct distribution; } \\
\text { small clusters of localities in } \\
\text { Louisiana, Mississippi, and } \\
\text { Alabama, and a more extensive } \\
\text { distribution from Northeast } \\
\text { Georgia into South Carolina }\end{array}$ & $180-3000$ & 130,000 & 1000 & Decreasing \\
\hline
\end{tabular}

In these three oak species, we ask whether range size, population size, and environmental variables correlate to genetic diversity within and among populations in situ. We then ask to what degree genetic diversity is preserved in botanic gardens and if this correlates to geographic range size. Specifically, we aim to:

- Assess levels of genetic diversity and differentiation in our focal species and compare them to other rare and common oak species (hypothesis: common oak species have more genetic diversity);

- Determine if genetic diversity and differentiation correlate with the relative range size of the three oak species (hypothesis: larger range size correlates to higher genetic diversity and higher genetic structure)

- Determine if genetic diversity and differentiation are correlated with demographic (e.g., population size) and/or environmental variables (hypothesis: lower genetic diversity in smaller populations; genetic diversity correlates with environmental variables);

- Quantify the amount of genetic diversity of each species that is conserved ex situ and determine whether this is correlated with features of those species (hypothesis: genetic diversity should be predicted by both the number of plants ex situ and the commonness of the species).

With 31\% of the United States' oak species now considered of conservation concern, results from this study should assist in assessing genetic diversity of the many other threatened oak species and designing management strategies for them, especially those for which genetic diversity is not available [18]. 

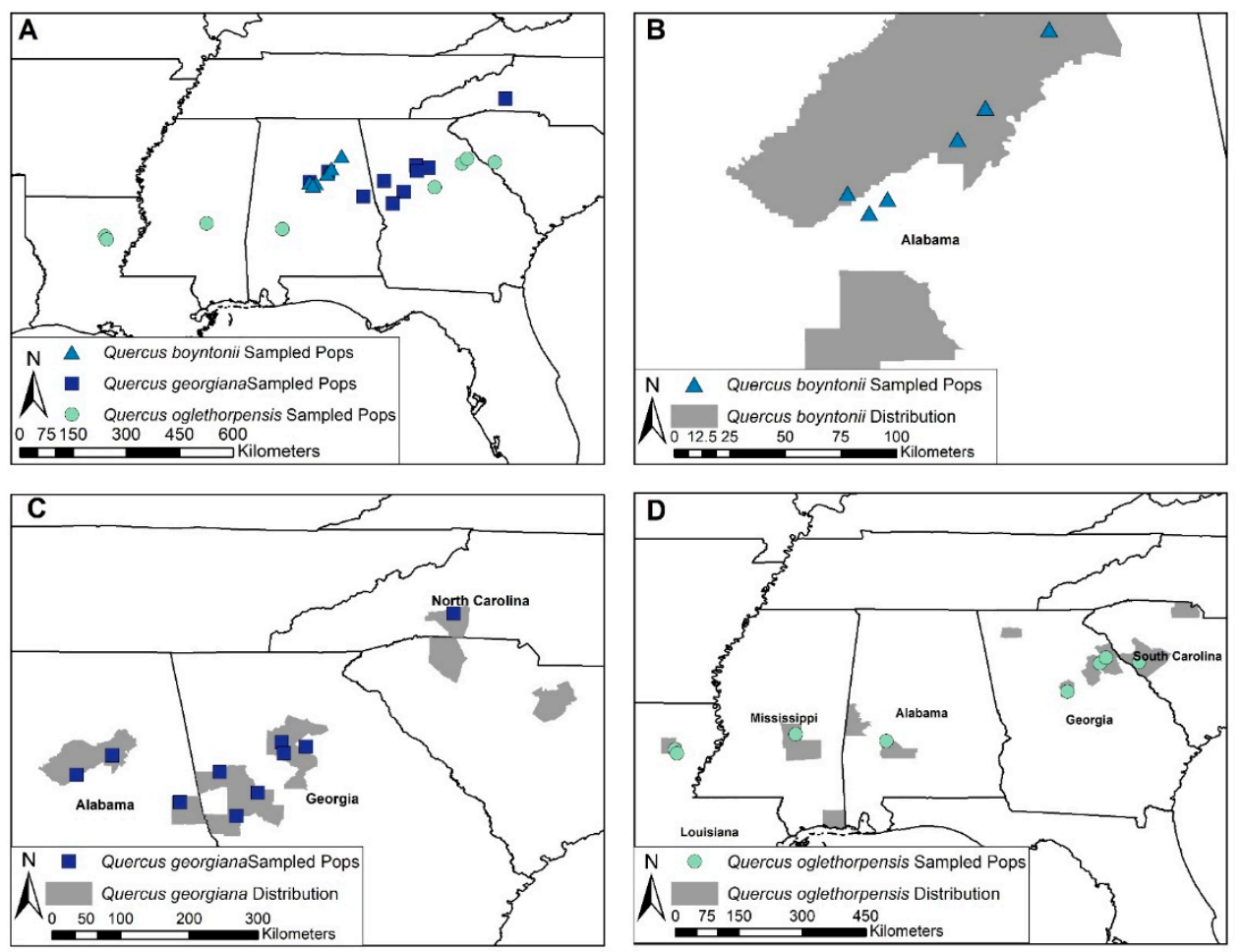

Figure 1. Sampled locations in relation to species geographic range; note that most extant occurrences were sampled. Range is based on county-level occurrences and is derived from USDA PLANTS. Panel (A) shows the sampling distribution of all three oak species included in the study; (B) depicts the known distribution of $Q$. boyntonii and sampled locations; (C) depicts the known distribution of Q. georgiana and sampled locations; (D) depicts the known distribution of Q. oglethropensis and sampled locations.

\section{Materials and Methods}

\subsection{Study Species, Sampling, and Genotyping}

These data were collected and used for a previous study answering different questions/in a different application [13]. Previously the data, along with genetic data of eight additional taxa of woody plant, were used to examine genetic diversity ex situ compared to in situ. We briefly described sampling and genotyping methods here for each focal species; complete collection and genotyping methods can be found in Hoban et al. 2020 [13]. For each species, we collected in situ samples from as many known populations as possible, and selected only trees representative of typical leaf morphologies for each focal species to avoid any possible hybrids. However, it is possible some hybrids were sampled because gene flow among oak species can occur (see Discussion). To find ex situ samples, we used Botanic Gardens Conservation International PlantSearch (https:/ / members.bgci.org/data_tools/plantsearch, accessed on 2017), a global database of more than 1000 botanic gardens and their collections.

Quercus boyntonii (Alabama sandstone post oak) is endemic to Alabama (USA.), although historical records say that it formerly grew in Texas [34]. It is a shrub or small tree, sometimes reaching a height of $6 \mathrm{~m}$, but usually smaller. Q. boyntonii was sampled ex situ from 16 botanic gardens and arboreta that have Q. boyntonii in their collections, totaling 87 individuals. In situ individuals were sampled in natural preserves, private property, and suburban parks. In situ population sizes ranged from fewer than 10 to more than 100 trees. Occurrences of the species are patchy, coinciding with suitable remnant habitat: sandstone outcrops, ridges, and slopes. We sampled 246 in situ samples (227 included in final analysis after clones were removed). In situ samples were collected during May 2017, and ex situ samples were collected between April and September 2017. Due to the patchiness of habitat, occurrence, and wind pollination it is challenging to delimit 
strict "populations". For these analyses, we used $8 \mathrm{~km}$ distance to delineate populations in instances of continuous distributions. We genotyped all individuals using 11 neutral microsatellites from previous studies in oaks. Extraction, testing of the larger panel of markers from which our microsatellites were drawn, and genotyping are discussed in detail in Hoban et al. 2020 [13].

Quercus georgiana (Georgia oak) is native to the Southeastern United States, mainly in Northern Georgia, but with additional populations in Alabama, North Carolina, and South Carolina. It grows on dry granite and sandstone outcrops of slopes of hills at 50-500 meters' altitude [35]. Quercus georgiana is a small tree, often shrubby in the wild, growing to 8-15 $\mathrm{m}$ tall. Quercus georgiana was sampled from nine populations across the known range of the species through the use of herbarium records, collection data from botanic garden records, and USDA PLANTS Database (USDA 2012). All sampled populations were separated by at least $15 \mathrm{~km}$. A total of 226 samples (223 were retained with sufficient genetic data) were sampled in June 2011. At least 24 individual trees were randomly sampled from each site, and sampled plants were at least five meters apart. Seventeen botanical institutions in the United States, France, and Belgium shared samples, totaling 36 individuals. Eight nuclear and 11 expressed sequence tag (EST) microsatellite markers were used for genotyping, following extraction and genotyping methods detailed in Hoban et al. 2020 [13]. We expect EST microsatellites to have lower polymorphism information content as they are associated with transcribed regions of DNA [36]. Nuclear and EST markers were assessed separately for analysis.

Quercus oglethorpensis (Oglethorpe oak) is a long-lived woody plant endemic to the Southeastern United States. Extant and largely fragmented wild populations are documented in South Carolina, Georgia, Alabama, Mississippi, and Louisiana. Q. oglethorpensis has a disjunct distribution across its range, with smaller clusters of localities in Northeast Louisiana, Southeast Mississippi, and Southwest Alabama, and a more extensive and wellknown distribution from Northeast Georgia across the border into South Carolina. It grows to up to $25 \mathrm{~m}$ in height, and has leaves that are flat, narrowly-elliptical and usually without lobes. We prioritized sites with the most up-to-date occurrence data that was gathered in July 2015 during a germplasm collection effort [37]. We included additional sites not visited during the collection effort so that the greatest geographic distribution could be sampled. Sampled populations were separated by at least $9 \mathrm{~km}$. Eight in situ populations were visited for a total of 191 samples (187 were retained with sufficient genetic data). Ex situ samples were collected from 145 trees, representing 16 botanic gardens around the world. All samples were genotyped with 10 nuclear microsatellite markers following extraction and genotyping methods in Hoban et al. 2020 [13].

\subsection{Analysis: Basic Statistics}

We used the R v 3.6.3 (R Core Team, Vienna, Austria) package adegenet version 2.1.2 to convert genepop files to genind and genpop formats. We used the R package poppr version 2.8.3 [38] to identify potential clones (and to remove clones/duplicate genotypes before any other calculations), expected heterozygosity, number of alleles, and allelic richness; hierfstat version 0.4.22 [39] to calculate pairwise population $\mathrm{F}_{\mathrm{ST}}$ values; diveRsity version 1.9.9 [40] to calculate observed heterozygosity and inbreeding coefficient ( $\left.\mathrm{F}_{\mathrm{IS}}\right)$; and Demerelate version 0.9.3 to calculate measures of relatedness [39-44]. We also tested for signatures of recent bottlenecks using the heterozygote excess test in the BOTTLENECK software [45] with both the infinite allele model and the two phase model and the mode shift test. We performed an ANOVA with species as the factor and population as the unit of analysis, to test for differences among species in the main summary statistics. For this and subsequent tests we only used the nuclear SSRs because EST-SSRs have much lower heterozygosity and allelic richness and we only had them for one species. We also tested for isolation by distance with linear regression of genetic distance $\left(\mathrm{F}_{\mathrm{ST}}\right)$ on geographic distance among populations. All analysis scripts are available at https://github.com/smhoban/SE_oaks_genetics (accessed on 15 February 2021). 


\subsection{Influence of Environment on Genetic Diversity and Differentiation}

We obtained 19 standard bioclimatic variables from WorldClim 2.0 at a resolution of $2.5 \mathrm{~min}$ [46]. To determine if there is a relationship between local climatic variables and population-level genetics, for each species, we performed ordinary least squares linear regression [47] of each climatic variable on each of four basic population genetic summary statistics that we may expect to respond to local climate: expected heterozygosity, allelic richness, $\mathrm{F}_{\mathrm{ST}}$, and relatedness. All analysis scripts are available at https://github.com/ smhoban/SE_oaks_genetics (accessed on 15 February 2021).

\subsection{Influence of Local Population Size}

Following previous work [48-51], we calculated the percentage of genetic diversity conserved as the proportion of extant in situ alleles preserved in ex situ collections. We focused on alleles existing in the wild; we did not count alleles existing only in botanic garden collections. These data were previously presented in Hoban et al. 2020 [13] but were analyzed in a different context: comparing genetic diversity in ex situ collections among different genera and without regard to species range sizes.

\section{Results}

\subsection{Basic Results}

Genetic summary statistics for all three species include: $N$ of samples genotyped, genetic diversity, measured as expected heterozygosity $\left(\mathrm{H}_{\mathrm{e}}\right)$ and allelic richness $\left(\mathrm{A}_{\mathrm{r}}\right)$, genetic differentiation (pairwise $\mathrm{F}_{\mathrm{ST}}$ ) and relatedness (R), and estimated population size (Table 2). We only present one relatedness estimator [43], but the patterns were similar for all three measures tested. No populations showed significant bottleneck signatures using the heterozygote excess test and the two-phase model, although one population of each species did show a signature of a bottleneck using the heterozygote excess test and the infinite allele model. The smallest population of Q. oglethorpensis showed a "mode shift", though no heterozygote excess. For Q. georgiana a bottleneck signature was observed for five populations (half of the populations) but only for the EST-SSRs. No bottleneck was detected for Q. boyntonii or Q. georgiana with neutral microsatellites. Q. oglethorpensis, the largest-ranged species we sampled, and was the only species which showed significant isolation by distance.

Comparing these three rare species to a set of other Quercus studies, we found that the rare oaks in this study had among the lowest heterozygosity, and that Q. oglethorpensis had an exceptionally high inbreeding coefficient $\left(\mathrm{F}_{\mathrm{IS}}\right.$, Table A1).

Table 2. Summary statistics for each population and the average across populations. Reported is the population name (Pop name), the state the population is located (State, specific locality data is not provided given the rarity of the species), the number of samples ( $N$ samples genotyped) and number of unique multilocus genotypes (unique MLG), the expected heterozygosity $\left(\mathrm{H}_{\mathrm{exp}}\right)$, allelic richness $\left(\mathrm{A}_{\mathrm{r}}\right)$, mean pairwise $\mathrm{F}_{\mathrm{ST}}$, relatedness (Rel), and estimated number of trees based on direct observations in the field (Pop size est.).

\begin{tabular}{|c|c|c|c|c|c|c|c|c|}
\hline Species & Pop Name & State & $\begin{array}{c}\text { N Samples } \\
\text { Genotyped } \\
\text { (Unique MLG) }\end{array}$ & $H_{\text {exp }}$ & $\mathbf{A}_{\mathbf{r}}$ & $\begin{array}{c}\text { Mean } \\
\text { Pairwise FST }\end{array}$ & Rel & $\begin{array}{c}\text { Pop Size } \\
\text { est. }\end{array}$ \\
\hline \multirow{8}{*}{ Q. boyntonii } & IMLS032 & $\mathrm{AL}$ & $14(12)$ & 0.581 & 5.02 & 0.023 & -0.014 & 20 \\
\hline & IMLS048 & $\mathrm{AL}$ & $17(15)$ & 0.605 & 5.45 & 0.029 & 0.234 & 30 \\
\hline & IMLS068 & $\mathrm{AL}$ & $22(22)$ & 0.605 & 4.84 & 0.027 & 0.024 & 25 \\
\hline & IMLS138 & AL & $12(11)$ & 0.593 & 3.51 & 0.043 & 0.013 & 5 \\
\hline & IMLS280 & $\mathrm{AL}$ & $83(76)$ & 0.642 & 5.85 & 0.015 & 0.05 & 165 \\
\hline & IMLS244 & $\mathrm{AL}$ & $60(60)$ & 0.63 & 4.78 & 0.023 & 0.134 & 150 \\
\hline & IMLS307 & $\mathrm{AL}$ & $30(30)$ & 0.651 & 6.02 & 0.025 & -0.013 & 70 \\
\hline & AVERAGE & - & $34(32)$ & 0.615 & 5.07 & 0.026 & 0.061 & 66 \\
\hline
\end{tabular}


Table 2. Cont.

\begin{tabular}{|c|c|c|c|c|c|c|c|c|}
\hline Species & Pop Name & State & $\begin{array}{l}\text { N Samples } \\
\text { Genotyped } \\
\text { (Unique MLG) }\end{array}$ & $H_{\text {exp }}$ & $\mathbf{A}_{\mathbf{r}}$ & $\begin{array}{c}\text { Mean } \\
\text { Pairwise } \text { F }_{S T}\end{array}$ & Rel & $\begin{array}{c}\text { Pop Size } \\
\text { est. }\end{array}$ \\
\hline \multirow{11}{*}{ Q. georgiana } & MR24 & $\mathrm{AL}$ & 24 & 0.738 & 7.355 & 0.051 & 0.031 & 24 \\
\hline & EDEN32 & AL & 25 & 0.624 & 7.739 & 0.056 & -0.056 & 50 \\
\hline & Pen32 & $\mathrm{AL}$ & 26 & 0.736 & 7.506 & 0.062 & 0.156 & 50 \\
\hline & CB32 & GA & 24 & 0.709 & 6.827 & 0.049 & 0.075 & 100 \\
\hline & DK32 & GA & 25 & 0.677 & 7.503 & 0.046 & 0.123 & 100 \\
\hline & CR31 & GA & 24 & 0.677 & 6.656 & 0.056 & 0.069 & 50 \\
\hline & SM32 & GA & 26 & 0.732 & 8.114 & 0.042 & 0.167 & 100 \\
\hline & am29 & GA & 25 & 0.803 & 9.706 & 0.039 & 0.131 & 100 \\
\hline & WGHerb & GA & 25 & 0.769 & 8.993 & 0.044 & 0.415 & 30 \\
\hline & COP-9 & $\mathrm{NC}$ & 26 & 0.588 & 5.03 & 0.074 & -0.043 & 200 \\
\hline & AVERAGE & - & 25 & 0.705 & 7.54 & 0.052 & 0.107 & 80 \\
\hline \multirow{7}{*}{$\begin{array}{c}Q . \\
\text { oglethorpensis }\end{array}$} & RMS-9 & LA & 14 & 0.645 & 5.9 & 0.069 & 0.017 & 200 \\
\hline & BIE-3-7 & MS & 33 & 0.694 & 6.03 & 0.052 & -0.025 & 50 \\
\hline & CAT-9 & $\mathrm{AL}$ & 27 & 0.639 & 6.25 & 0.054 & 0.075 & 60 \\
\hline & MOT-9 & GA & 31 & 0.653 & 5.56 & 0.073 & 0.172 & 500 \\
\hline & BUF-9 & GA & 29 & 0.62 & 5.75 & 0.059 & 0.008 & 50 \\
\hline & SUM-9 & SC & 28 & 0.648 & 6.06 & 0.055 & 0.028 & 40 \\
\hline & AVERAGE & - & 27 & 0.65 & 5.93 & 0.06 & 0.046 & 150 \\
\hline
\end{tabular}

\subsection{Genetic Diversity and Range Size for Our Three Rare Oaks}

Range size shows some relationship to heterozygosity and allelic richness, in that Q. boyntonii (the most geographically restricted species) had the lowest heterozygosity and allelic richness (Figure 2). However, Q. georgiana had the highest heterozygosity even though its range size was moderate. Range size strongly related to genetic differentiation as measured by $F_{\mathrm{ST}}$. All ANOVA test comparisons were significant except $Q$. georgiana, $Q$. oglethorpensis for allelic richness and Q. boyntonii, Q. oglethorpensis for allelic richness and expected heterozygosity.
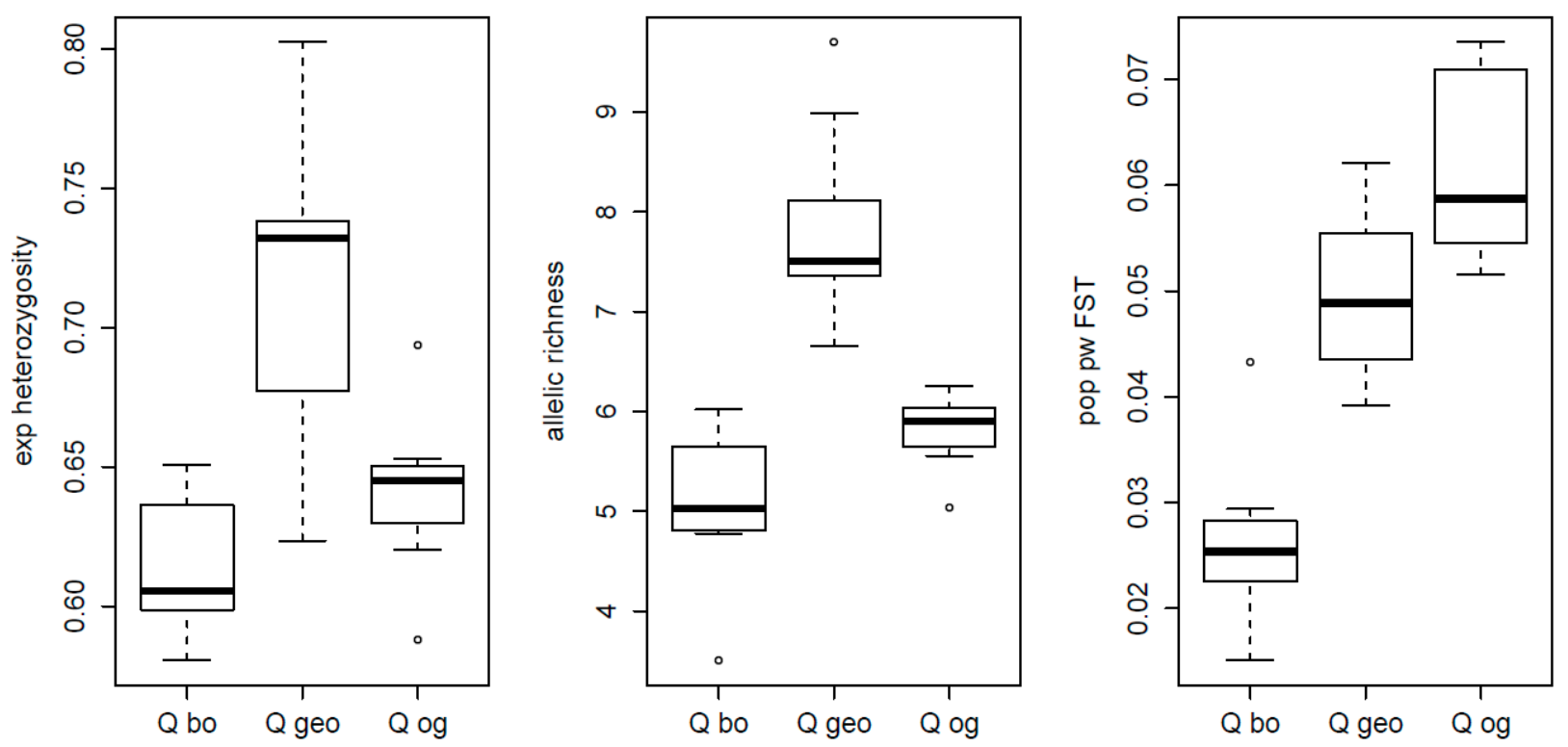

Figure 2. Species genetic diversity boxplots across populations comparing expected heterozygosity (exp heterozygosity), allelic richness, and $\mathrm{F}_{\mathrm{ST}}$. (pop pw $\mathrm{F}_{\mathrm{ST}}$ ) Species are arranged by range size, with the smallest range on the left (Q. boyntonii, "Q bo"), followed by Q. georgiana ("Q geo"), and the largest species range on the right (Q. oglethorpensis, "Q og"). Only nuclear SSRs are included in this analysis. 


\subsection{Genetic Diversity and Range Size within Each Species}

Genetic diversity and differentiation statistics are presented in Appendix B for populations above and below $\mathrm{N}_{\mathrm{c}}$ of 50 individuals. For two species, Q. boyntonii and Q. georgiana, the trends were as predicted, with allelic richness and heterozygosity generally higher in larger populations and $\mathrm{F}_{\mathrm{ST}}$ generally lower for larger populations (Figure A2). Though statistically significant $p$-value differences were observed in only a few comparisons, all other comparisons were not significantly different (Figure A2). Additionally, in these two species, relatedness generally showed no difference. For the third species, Q. oglethorpensis, the opposite pattern was observed, with lower genetic diversity, higher differentiation and higher relatedness in larger populations.

\subsection{Genetic Diversity and Environment}

Genetic diversity and differentiation were not related to climate variables for $Q$. georgiana and Q. oglethorpensis when testing all 19 bioclimatic variables at $2.5 \mathrm{~min}$-none were significant after correcting for multiple testing.

\subsection{Genetic Diversity in Ex Situ Collections}

The percentage of genetic diversity currently preserved in ex situ collections is shown in Table 3. The percentage was not clearly related to species range size or to the number of ex situ samples; although $Q$. boyntonii had the smallest range and moderate number of samples, it had the lowest genetic diversity ex situ. Note that EST diversity was not conserved (Figure A3).

Table 3. Percent allele capture in ex situ collections. The percent of alleles conserved in ex situ collections, for different allele frequency categories, for each species. Allele frequency categories are: all (all alleles); very common alleles ( $>10 \%)$; common alleles $(>5 \%)$; low $(<10 \%$ and $>1 \%)$; and rare $(<1 \%)$. For rare alleles and all alleles, two results are presented, percentage captured when all alleles including those with fewer than two occurrences are included (complete data), and when alleles with one or two occurrences are excluded (reduced data, shown in parentheses).

\begin{tabular}{|c|c|c|c|c|c|c|c|}
\hline \multirow[b]{2}{*}{ Species } & \multirow[b]{2}{*}{$\begin{array}{l}N \text { Plants } \\
\text { Ex Situ }\end{array}$} & \multirow[b]{2}{*}{$\begin{array}{l}\text { Geographic } \\
\text { Range Size }\end{array}$} & \multicolumn{5}{|c|}{ Allele Frequency Category (\%) } \\
\hline & & & All & $\begin{array}{c}\text { Very } \\
\text { Common }\end{array}$ & Common & $\begin{array}{c}\text { Low } \\
\text { Frequency }\end{array}$ & Rare \\
\hline Q. oglethorpensis & 145 & large & $78(94)$ & 100 & 100 & 97 & $37(67)$ \\
\hline Q. georgiana (EST-SSR) & 36 & medium & $61(68)$ & 100 & 85 & 51 & $33(33)$ \\
\hline Q. georgiana (nSSR) & 36 & medium & $69(76)$ & 100 & 100 & 75 & $35(41)$ \\
\hline Q.boyntonii & 77 & small & $60(70)$ & 100 & 100 & 66 & $32(29)$ \\
\hline
\end{tabular}

\subsection{Other Observations}

We only identified clones in Quercus boyntonii. For this species we often observed small "rings" or clusters of stems, sometimes 5 or more meters across. We found 12 pairs of clones, which werealways were adjacent individuals, either stems sampled immediately next to each other or within a few meters.

As expected, we found that EST-SSR markers had lower diversity than nuclear SSR markers, with heterozygosity and the number of alleles being 19\% and $14 \%$ lower on average, respectively.

\section{Discussion}

Our study tested the influence of range size, environmental and demographic variables on genetic diversity, and differentiation in three rare oak species. Our main findings are as follows. (1) These three rare species generally have lower genetic diversity than more common oaks previously studied, and range size relates strongly to genetic differentiation but less strongly to genetic diversity. (2) In spite of relatively small numbers of populations 
available, due to the rarity of these species, we found that in some cases small population size and geographic range may correlate with some metrics of genetic diversity and differentiation. (3) We also found that genetic diversity currently conserved varies among species of comparable geographic range size and numbers of samples preserved. Thus, our study supports the idea that "rarity" and collection history are not sufficient to explain genetic diversity in ex situ collections: the amount of genetic diversity preserved is also a function of intrinsic biology, demography, or life histories that vary independently of rarity.

We first present our observations in the context of rare and common species in the genus. Many population genetic studies have been performed in Quercus [52,53]. Genetic diversity is often summarized using allelic richness and heterozygosity. Expected heterozygosity was lower in our study (less than 0.65 for most populations, and a mean of 0.641 for Q. oglethorpensis, 0.615 for Q. boyntonii, and 0.72 for Q. georgiana) than was observed in other oaks, which typically had heterozygosities between 0.7 and 0.9 (Table A2). However, some common oaks were observed with lower genetic diversity (e.g., Q. phillyreoides, $\mathrm{H}_{\mathrm{e}}=0.535$ ) and some rare oaks were observed with higher genetic diversity (e.g., Q. pacifica $\left(\mathrm{H}_{\mathrm{e}}=0.851\right)$ and Q. hinckleyi $\left(\mathrm{H}_{\mathrm{e}}=0.853\right)$ as estimated using microsatellites. Some oaks were postulated to be naturally rare (e.g., $Q$. boyntonii), others were more likely to be rare due to human disturbance (e.g., Q. arkansana), and others were increasing in rarity for a long time (e.g., Q. hinckleyi) [27]. Due to the relatively long-lived nature of most oak species (100+ years), it is possible that recently rare oaks may take a long time to show the subsequent genetic impacts of a drop in population size and narrowing ranges that are associated with their increasing rarity. This form of "extinction debt" has been shown in simulations $[12,54]$, while more naturally rare oaks would not be expected to show such genetic impacts. The relatively low genetic diversity in the species we studied may be due to relatively low population sizes over multiple generations.

Comparing genetic diversity statistics for these three species with different range sizes we see that $Q$. boyntonii has lowest heterozygosity and allelic richness as expected based on small range and highest endangerment status. However, Q. oglethorpensis and Q. georgiana had relatively equal allelic richness, and Q. georgiana had the highest heterozygosity even though its range size was moderate. It is not surprising that overall range size was only a moderate predictor of genetic diversity, as it is the local effective population size that influences retention of genetic diversity within populations (see next section). The paucity of bottleneck signatures may suggest the species have not suffered bottlenecks, or that bottleneck signatures have not had time to develop (as in other species with known, recent population collapses, e.g., Juglans cinerea, [55]); bottleneck tests are unreliable for recent, moderate, or gradual bottlenecks [54].

On the other hand, $\mathrm{F}_{\mathrm{ST}}$ is related to species range size for these three species: the smallest-range species ( $Q$. boyntonii) had lowest $\mathrm{F}_{\mathrm{ST}}$, and the species with the largest range size and most general habitat preference (Q. oglethorpensis) had highest the $\mathrm{F}_{\mathrm{ST}}$ (Figure 2). This conforms to population genetic theory regarding isolation by distance, whereby populations of a large range species have the most distance among them, and genetic distance is known to increase with geographic distance. Thus, in our study the influence of range size was much more apparent on among population genetic differentiation than on within population genetic diversity. Of course range size is not the only predictor of $\mathrm{F}_{\mathrm{ST}}$, factors such as connectivity can also be used to predict $\mathrm{F}_{\mathrm{ST}}$. For example, wide ranging oak species with high numbers of populations, and thus high gene flow, can show low $\mathrm{F}_{\mathrm{ST}}$ (e.g., in Q. macrocarpa [56]).

According to conservation genetic theory we would expect that populations near or below a population size of 50 individuals would be subject to strong genetic drift. The exact threshold for a population to rapidly suffer detrimental genetic consequences has been hotly debated $[7,57,58]$, but here we focused on 50 individuals. For our study we would predict lower allelic richness and heterozygosity, and high $\mathrm{F}_{\mathrm{ST}}$ and relatedness in such populations. We see this predicted pattern in Q. georgiana and Q. boyntonii, though comparisons were significant or nearly so only for $\mathrm{F}_{\mathrm{ST}}$ in Q. georgiana (all loci $t$ test 0.055 , 
Wilcox 0.063; ESTs $t$ test 0.04 , Wilcox 0.063 ) and heterozygosity for $Q$. boyntonii ( $t$ test 0.003, Wilcox 0.057). The relatively low number of significant values emphasizes the small number of replicate populations (inherent in rare species) and the fact that for very recently reduced populations, genetic diversity impacts may not yet have accumulated [55].

Interestingly, for $Q$. oglethorpensis all statistics are in the opposite direction of what might be predicted based on a large population size (higher $\mathrm{F}_{\mathrm{ST}}$, higher relatedness, lower heterozygosity, and lower allelic richness). It is not clear why $Q$. oglethorpensis shows this pattern. This could be a result of fragmentation coupled with the fact that Q. oglethorpensis grows predominantly as a subcanopy tree [59]. Although not well-studied in wind pollinated trees, subcanopy habit could possibly limit pollen dispersal [60]. However, this pattern would be consistent with recent expansions or founding populations, which would result in moderate population size but reduced genetic diversity and increased $\mathrm{F}_{\mathrm{ST}}$.

There was no relationship between environmental variables and genetic statistics. It is possible that for these species, neutral genetic diversity is more influenced by current population sizes, which may be impacted by processes other than environment, such as land development, loss of habitat, etc. It is also possible that neutral genetic diversity and demography are influenced by environment but at fine spatial scales and/or along unmeasured environmental axes. Useful future work will be to create ecological niche models for each species to test for the impact of habitat suitability/probability of occurrence in relation to genetic diversity [61-63]. All three species are habitat specialists with typically very restricted populations.

Although the very common and just common alleles are preserved well in ex situ collections, low frequency and rare alleles are not conserved well, and overall, only a moderate amount of genetic diversity is preserved ex situ, between 60 and $78 \%$ for these species assuming all alleles are considered (68-94\% if the rarest alleles are dropped). Previous modeling work suggests that the species with the largest range and highest $\mathrm{F}_{\mathrm{ST}}$ would require the most samples [11,12]. Quercus oglethorpensis is preserved extremely well, at $78 \%$, even though it has the largest range; it does have the most individuals ex situ. Less of the genetic variation of $Q$. boyntonii is conserved than of $Q$. georgiana, even though $Q$. boyntonii has the smaller range and about twice the number of individuals ex situ. Other studies of the genetic diversity conserved ex situ have primarily been species specific and we are only aware of a few attempts to determine if genetic diversity ex situ correlates to range size. In the plant genus: Zelkova, Christe et al. [64] found that a small-range endemic was less well conserved than a larger-range species. Several reasons can explain their similar findings: for the rare species, collectors may have revisited a single accessible site for seed collection, even though it occurred across high topographic and ecological diversity, while for the common species collectors in multiple countries had visited numerous populations. In other words, accessibility and availability of sampling are important to consider.

Although more than 3000 botanical institutions maintain more than 100,000 globally threatened species ex situ [65], the conservation value of these collections is unclear. Most taxa are held in a small number of collections, usually with a small number of inadequately documented accessions $[66,67]$. While some collections maintain relatively high levels of genetic diversity $[68,69]$, research on the genetic representativeness of species in living collections is sparse. Our results emphasize that the genetic diversity conserved in collections is not only a function of the number of samples conserved, nor simply a function of the species inherent characteristics such as range size. Rather, the amount of genetic diversity conserved is likely a function of the interaction number of samples, range size, and collection strategy (such as which populations are visited, the spatial sampling within populations, the number of maternal plants collected from, etc.) [51,70]. While Q. oglethorpensis is conserved quite well, $Q$. boyntonii and $Q$. georgiana may need more individuals sampled to better represent in situ diversity. 


\section{Caveats}

We used microsatellites because they are an affordable method to achieve an understanding of genetic diversity and structure. We recognize that increased resolution could be obtained with next generation sequencing techniques [71,72]. It is known that microsatellites that are developed in one species and applied in a different species can show reduced genetic diversity due to PCR amplification failure caused by mutations in primer binding sites. The markers applied to our species were all developed from other species of oaks, but were developed in Quercus subgenus Quercus sections to which they were applied (red oak markers from Section Lobatae for the one red oak species, and white oak markers from Section Quercus for the two white oak species). However, this is also the case for nearly all microsatellite studies of oaks: the majority of microsatellites were developed in European white oaks and then applied in diverse species (Table A2). It is also known that microsatellites are susceptible to ascertainment bias, such that the investigator will select markers that are polymorphic in a small sample of test individuals, such that less polymorphic markers are not included in the study. We did not have an a priori expectation that the patterns we saw between species were due to this reason, as this should apply to all oak species using these markers.

Other caveats involve the populations we studied. There are likely some populations of these species that we are unaware of, and we sometimes were not able to collect all of the individuals within a population. Moreover, genetic diversity in some populations may reflect gene flow from other species. It is known that gene flow among related oak species does occur, often at low levels and that hybridization may be even higher in species that have low population numbers due to the phenomenon of pollen swamping, where heterospecific pollen may far outnumber conspecific pollen [73,74]. For instance, in the extremely rare $Q$. hinckleyi, hybrids have been identified with genetic markers [52]. We did attempt to only sample individuals consistent with the phenotype of the target species. Of course, any of these caveats would obscure the patterns that we were testing for, and it is possible that if such caveats could be taken into account (for example identifying and removing all hybrids), the patterns we found here might be stronger.

\section{Conclusions and Conservation Implications}

We found that genetic diversity and differentiation were influenced by both population size and range size, but that patterns did not perfectly accord to predictions. This emphasizes stochastic processes and the influence of multiple factors on genetic diversity we see today (time, human influence, and population recovery). We also found that genetic diversity conserved ex situ was not well predicted by species geographic range size or number of samples, in contrast to theoretical predictions, and that two species need more samples ex situ. The overall low genetic diversity in these three rare oaks relative to more common oaks suggest that genetic diversity may also be low in other threatened oak species, a supposition to be tested by analyzing several more threatened oaks. We note that $Q$. oglethorpensis, in spite of its wide geographic range, had lower allelic richness and heterozygosity than might be expected-nearly as low as the critically endangered and small range $Q$. boyntonii-and thus might already be suffering genetic erosion in its isolated populations.

Author Contributions: Conceptualization: E.S.S., J.B.F., O.G., M.P.G., K.H., A.K., A.L.H., M.W., J.W. and S.H.; methodology: E.S.S., J.B.F., O.G., B.A.Z. and S.H.; software: E.S.S. and S.H.; validation: E.S.S., J.B.F., O.G., M.P.G., K.H., A.L.H., J.W., B.A.Z. and S.H.; formal analysis: E.S.S., P.K., R.T., J.W. and S.H.; investigation: E.S.S., J.B.F., O.G., M.P.G., K.H., A.L.H., P.K., A.K., P.T., R.T., M.W., J.W., B.A.Z. and S.H.; resources, M.P.G., K.H., M.W. and S.H.; data curation, S.H.; writing-original draft preparation: E.S.S. and S.H.; writing-review and editing, E.S.S., J.B.F., O.G., M.P.G., K.H., A.L.H., B.A.Z. and S.H.; visualization: E.S.S. and S.H.; supervision, J.B.F., K.H., O.G., M.W. and S.H.; project administration: J.B.F., M.P.G., K.H. and S.H.; funding acquisition: J.B.F., M.P.G., K.H., A.L.H., A.K., P.T., M.W., J.W. and S.H. All authors have read and agreed to the published version of the manuscript. 
Funding: This research was funded by the institute of Museum and library Services, grant number MG-30-16-0085-16, and also in part by the Center for Tree Science at the Morton Arboretum.

Institutional Review Board Statement: Not applicable.

Data Availability Statement: The data and code for analyses used in this study are openly available on the Github repository: https://github.com/smhoban/SE_oaks_genetics (accessed on 15 February 2021).

Acknowledgments: This was truly a group effort, with so many wonderful collaborators to thank. The authors would like to thank all permit-granting agencies, all institutions who voluntarily sent samples, and all the individuals and institutions who aided in collection of wild material. We would like to thank Cindy Johnson, Kevin Feldheim, and Isabel Distefano for volunteering their time and expertise. Additionally, we thank the Field Museum for providing us access to equipment for microsatellite analysis.

Conflicts of Interest: The authors declare no conflict of interest. The funders had no role in the design of the study; in the collection, analyses, or interpretation of data; in the writing of the manuscript, or in the decision to publish the results.

\section{Appendix A}

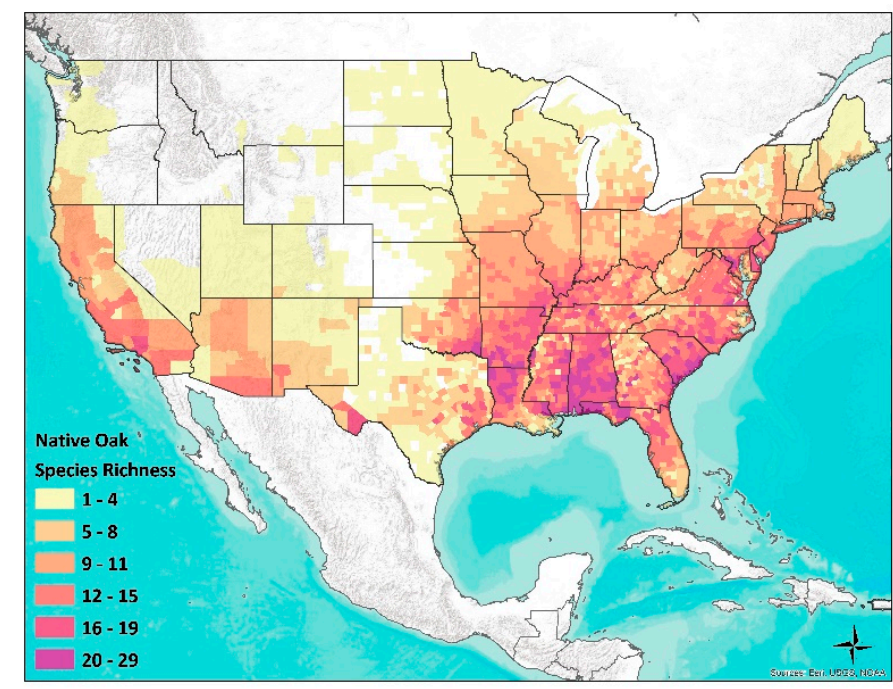

Figure A1. Native U.S. oak species richness by county. County level distribution data from USDA PLANTS and Biota of North America Program (BONAP) were combined to estimate species richness.

Table A1. The matrix of rarity as presented by Rabinowitz mapped with three rare oaks (Q. boyntonii, Q. georgiana, and Q. oglethorpensis) and three oaks which are common by two measures (geographic range and habitat) but rare in abundance ( $Q$. hemisphaerica, $Q$. incana, and $Q$. laevis). The three rare species group together in the same rarity ranking, while the three common oaks group together in a different rarity ranking. Bold font indicates species is in the subgenus Erythrobalanus (red oak), regular font indicates species is in the subgenus Leucobalanus (white oak).

\begin{tabular}{|c|c|c|c|c|}
\hline Geographic Range & \multicolumn{2}{|c|}{ Large } & \multicolumn{2}{c|}{ Small } \\
\hline Habitat Specificity & \multicolumn{1}{|c|}{ Wide } & Narrow & Wide & Narrow \\
\hline Local Population Size & \multicolumn{2}{|l|}{} & \\
\hline $\begin{array}{c}\text { Large, Dominate } \\
\text { somewhere }\end{array}$ & & & $\begin{array}{l}\text { Q. boyntonii } \\
\text { Q. georgiana } \\
\text { Small, nonlethorpensis }\end{array}$ \\
\hline $\begin{array}{l}\text { Q. hemisphaerica } \\
\text { Q. incana } \\
\text { Q. laevis }\end{array}$ & & & \\
\hline
\end{tabular}


Table A2. Literature review and comparison of previously published population genetic studies of oak species and species accessed in this study.

\begin{tabular}{|c|c|c|c|c|c|c|c|c|c|c|c|c|c|c|c|}
\hline Species & Section & $\begin{array}{l}\text { IUCN } \\
\text { Status }\end{array}$ & AOO & EOO & \# of Loci & \# of Pops & $\begin{array}{l}\text { Sample } \\
\text { Size }(N)\end{array}$ & $\mathrm{F}_{\mathrm{ST}}$ & $\mathrm{G}_{\mathrm{ST}}$ & $\begin{array}{c}\text { Mean } \\
\text { Number } \\
\text { of Alleles }\end{array}$ & AR & $\mathbf{H}_{\mathrm{o}}$ & $\mathrm{H}_{\mathrm{e}}$ & $\mathrm{F}_{\text {IS }}$ & Citation \\
\hline $\begin{array}{c}\text { Quercus } \\
\text { phillyraeoides }\end{array}$ & Cerris & $N E N$ & NR & NR & 11 & 24 & 536 & 0.097 & 0.09 & 10.45 & 4.47 & 0.51 & 0.54 & 0.079 & [75] \\
\hline Quercus georgiana & Lobatae & $E N$ & 272 & 21,600 & 8 & 9 & 224 & 0.049 & NR & 8.03 & 7.82 & 0.72 & 0.69 & 0.019 & - \\
\hline Quercus rubra & Lobatae & $L C$ & NR & $4,150,115$ & 10 & 23 & 980 & 0.044 & NR & NR & $5.5-12.14$ & NR & NR & NR & [76] \\
\hline $\begin{array}{c}\text { Quercus } \\
\text { berberidifolia }\end{array}$ & Quercus & $L C$ & NR & 250,000 & 8 & 2 & 60 & NR & NR & 18.6 & 5.72 & 0.85 & 0.88 & 0.039 & [52] \\
\hline Quercus boyntonii & Quercus & $C R$ & 24 & 4,157 & 9 & 7 & 238 & 0.026 & NR & 7.24 & 5.07 & 0.62 & 0.55 & 0.061 & - \\
\hline Quercus dumosa & Quercus & $E N$ & 620 & 12,500 & 8 & 2 & 24 & NR & NR & 11.1 & 4.9 & 0.77 & 0.8 & 0.029 & [77] \\
\hline Quercus hinckleyi & Quercus & $C R$ & 30 & 380 & 8 & 4 & 123 & NR & 0.03 & 13.06 & $5.15-14.73$ & 0.81 & 0.85 & 0.036 & [52] \\
\hline Quercus lobata Née & Quercus & NT & NR & 280,000 & 8 & 12 & 270 & 0.064 & NR & 8.12 & NR & 0.8 & 0.7 & -0.196 & [78] \\
\hline Quercus macrocarpa & Quercus & $L C$ & NR & 4056,799 & 5 & 14 & 480 & 0.027 & NR & 11.184 & NR & 0.92 & 0.86 & NR & {$[79,80]$} \\
\hline $\begin{array}{c}\text { Quercus } \\
\text { oglethorpensis }\end{array}$ & Quercus & $E N$ & 3000 & 130,000 & 9 & 7 & 188 & 0.062 & NR & 6.81 & 5.8 & 0.64 & 0.48 & 0.234 & - \\
\hline Quercus pacifica & Quercus & $E N$ & NR & 3800 & 8 & 3 & 133 & 0.233 & NR & 15.8 & 5.54 & 0.81 & 0.85 & 0.05 & [77] \\
\hline Quercus tomentella & Protobalanus & $E N$ & 250 & 43,500 & 8 & 6 & 345 & NR & NR & 16.3 & 3.63 & 0.56 & 0.76 & 0.262 & [53] \\
\hline $\begin{array}{l}\text { AVERAGE of } \\
\text { previously } \\
\text { studied species }\end{array}$ & & & 300 & $1,079,677$ & 8 & 10 & 305 & 0.093 & 0.06 & 13.45 & 4.82 & 0.75 & 0.79 & 0.056 & \\
\hline $\begin{array}{l}\text { AVERAGE of } \\
\text { all species }\end{array}$ & & & 699 & 822,738 & 8 & 9 & 285 & 0.075 & 0.06 & 11.92 & 5.29 & 0.72 & 0.73 & 0.069 & \\
\hline
\end{tabular}

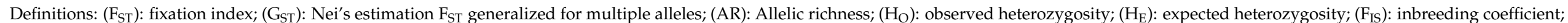
(NR): Not Reported. The IUCN status abbreviations are as follows: (NE): Not Evaluated; (LC): Least Concern; (NT): Near Threatened; (EN): Endangered; (CR): Critically Endangered. 


\section{Appendix B}
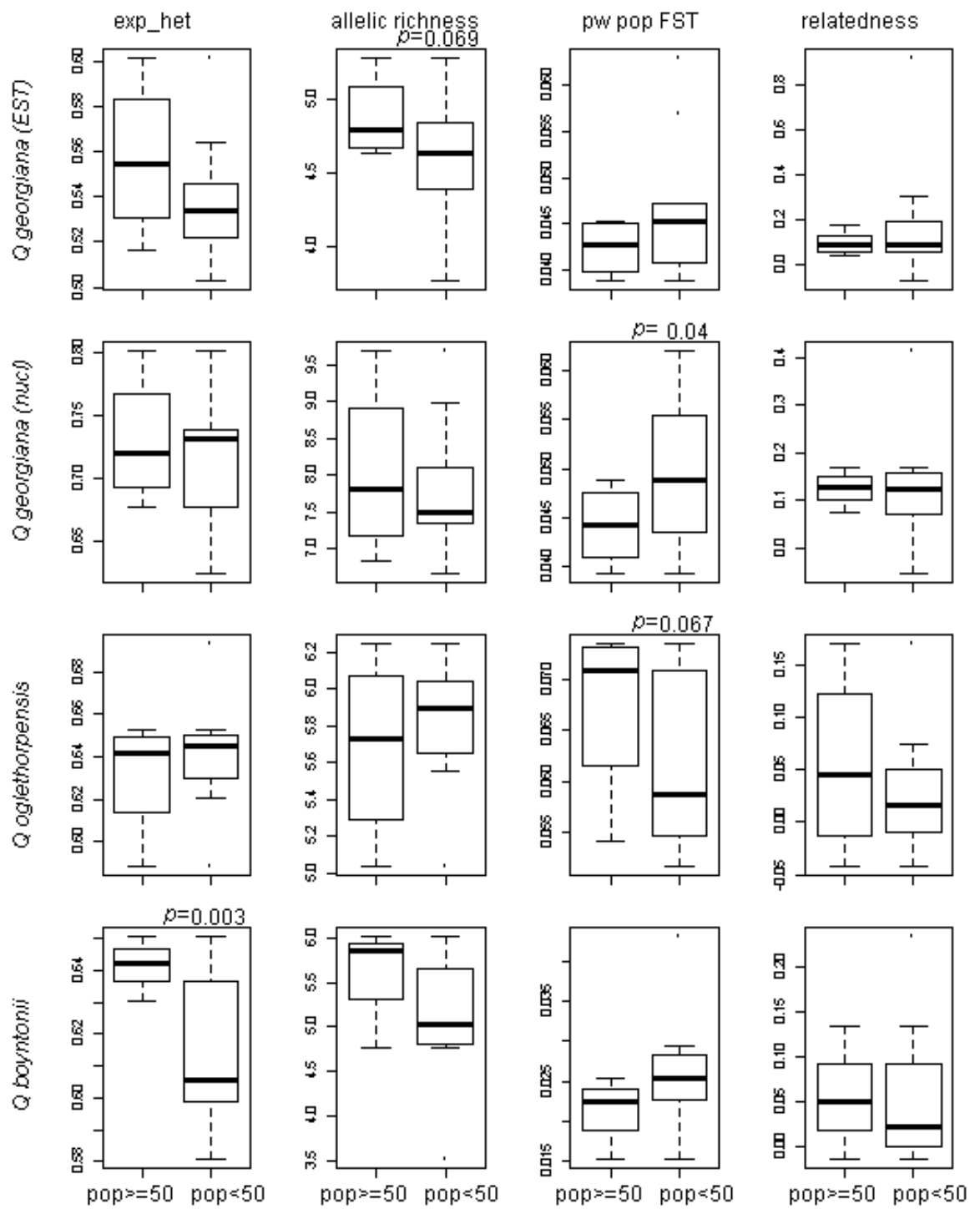

Figure A2. Box and whisker plots for each species by genetic summary. Each column of graphs represents different genetic summary statistics: (exp_het): expected heterozygosity; allelic richness; (pw pop FST): Pairwire population $\mathrm{F}_{\mathrm{ST}}$; and relatedness. Within each graph, the boxplot on the right represents populations with greater than or equal to 50 individuals (pop $>=50$ ) and less than 50 individuals (pop <50). 

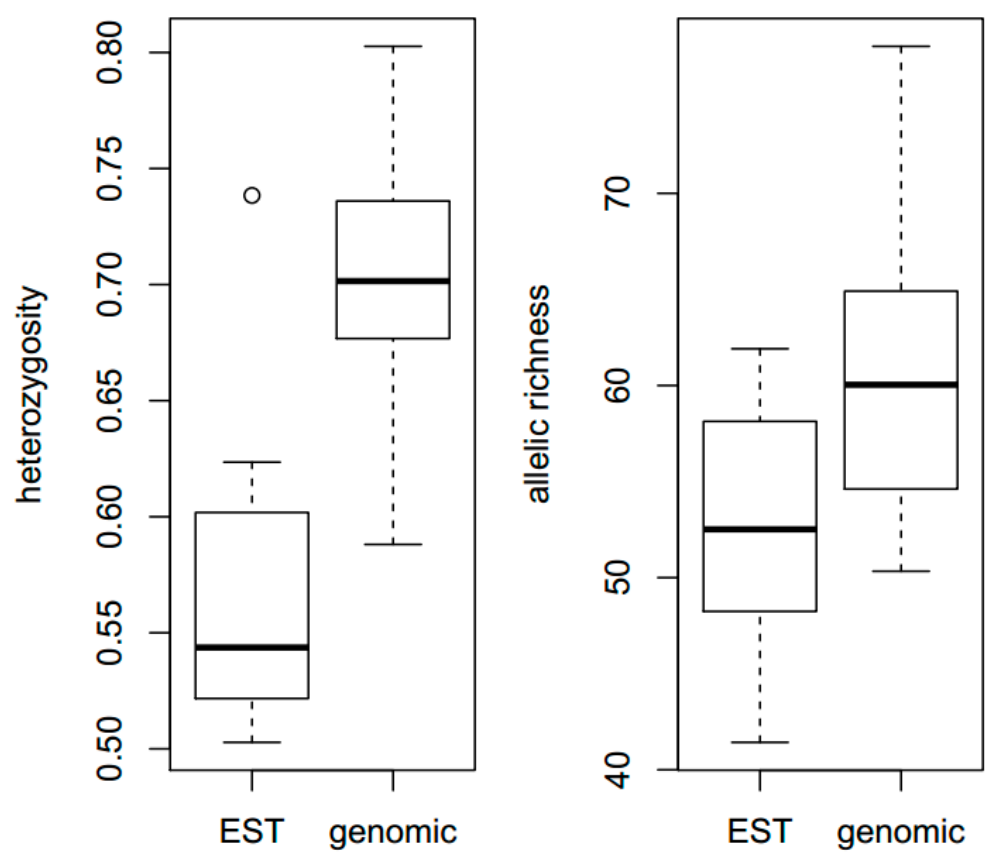

Figure A3. Box and whisker plots comparing heterozygosity and allelic richness between EST and genetic markers for the same species/samples.

\section{References}

1. Guerrant, E.O.; Havens, K.; Vitt, P. Sampling for Effective Ex Situ Plant Conservation. Int. J. Plant Sci. 2014, 175, 11-20. [CrossRef]

2. Namoff, S.; Husby, C.E.; Francisco-Ortega, J.; Noblick, L.R.; Lewis, C.E.; Griffith, M.P. How well does a botanical garden collection of a rare palm capture the genetic variation in a wild population? Biol. Conserv. 2010, 143, 1110-1117. [CrossRef]

3. Whitlock, R.; Hipperson, H.; Thompson, D.B.A.; Butlin, R.K.; Burke, T. Consequences of in-situ strategies for the conservation of plant genetic diversity. Biol. Conserv. 2016, 203, 134-142. [CrossRef]

4. Frankham, R. Relationship of Genetic Variation to population size in wildlife. Conserv. Biol. 1996, 10, 1500-1508. [CrossRef]

5. Pelletier, T.A.; Carstens, B.C. Geographical range size and latitude predict population genetic structure in a global survey. Biol. Lett. 2018, 14, 20170566. [CrossRef]

6. Hamrick, J.L.; Godt, M.J.W. Effects of life history traits on genetic diversity in plant species. Philos. Trans. R. Soc. Lond. B Biol. Sci. 1996, 351, 1291-1298. [CrossRef]

7. Frankham, R.; Bradshaw, C.J.A.; Brook, B.W. Genetics in conservation management: Revised recommendations for the 50/500 rules, Red List criteria and population viability analyses. Biol. Conserv. 2014, 170, 56-63. [CrossRef]

8. Kremer, A.; Potts, B.M.; Delzon, S. Genetic divergence in forest trees: Understanding the consequences of climate change. Funct. Ecol. 2014, 28, 22-36. [CrossRef]

9. Sork, V.L.; Davis, F.W.; Westfall, R.; Flint, A.; Ikegami, M.; Wang, H.; Grivet, D. Gene movement and genetic association with regional climate gradients in California valley oak (Quercus lobata Née) in the face of climate change. Mol. Ecol. 2010, 19, 3806-3823. [CrossRef]

10. Eckert, C.G.; Samis, K.E.; Lougheed, S.C. Genetic variation across species' geographical ranges: The central-marginal hypothesis and beyond. Mol. Ecol. 2008, 17, 1170-1188. [CrossRef]

11. Hoban, S. New guidance for ex situ gene conservation: Sampling realistic population systems and accounting for collection attrition. Biol. Conserv. 2019, 235, 199-208. [CrossRef]

12. Hoban, S.; Schlarbaum, S. Optimal sampling of seeds from plant populations for ex-situ conservation of genetic biodiversity, considering realistic population structure. Biol. Conserv. 2014, 177, 90-99. [CrossRef]

13. Hoban, S.; Callicrate, T.; Clark, J.; Deans, S.; Dosmann, M.; Fant, J.; Gailing, O.; Havens, K.; Hipp, A.L.; Kadav, P.; et al. Taxonomic similarity does not predict necessary sample size for ex situ conservation: A comparison among five genera. Proc. R. Soc. B 2020, 287, 20200102. [CrossRef] [PubMed]

14. Jackson, P.W.; Kennedy, K. The Global Strategy for Plant Conservation: A challenge and opportunity for the international community. Trends Plant Sci. 2009, 14, 578-580. [CrossRef]

15. Cavender, N.; Westwood, M.; Bechtoldt, C.; Donnelly, G.; Oldfield, S.; Gardner, M.; Rae, D.; McNamara, W. Strengthening the conservation value of ex situ tree collections. Oryx 2015, 49, 416-424. [CrossRef]

16. Westwood, M.; Cavender, N.; Meyer, A.; Smith, P. Botanic garden solutions to the plant extinction crisis. Plants People Planet 2021, 3, 22-32. [CrossRef] 
17. Pence, V.C. In Vitro methods and the challenge of exceptional species for target 8 of the global strategy for plant conservation1. Ann. Mo. Bot. Gard. 2013, 99, 214-220. [CrossRef]

18. Carrero, C.; Jerome, D.; Beckman, E.; Byrne, A.; Coombes, A.J.; Deng, M.; González-Rodríguez, A.; Hoang, V.S.; Khoo, E.; Nguyen, N.; et al. The Red List of Oaks 2020; The Morton Arboretum: Lisle, IL, USA, 2020.

19. Jerome, D.; Beckman, E.; Kenny, L.; Wenzell, K.; Kua, C.-S.; Westwood, M. US Oaks; The Morton Arboretum: Lisle, IL, USA, 2017.

20. Connor, K.F. Update on oak seed quality research: Hardwood recalcitrant seeds. National Proceedings, forestry and conser-vation nursery associations-2003. Ogden (UT): USDA Forest Service. Rocky Mt. Res. Stn. Proc. RMRS-P-33 2004, 111-116.

21. Kramer, A.T.; Pence, V. The challenges of ex situ conservation for threatened oaks. Intl. Oaks 2012, 23, 91-108.

22. Fant, J.B.; Havens, K.; Kramer, A.T.; Walsh, S.K.; Callicrate, T.; Lacy, R.C.; Maunder, M.; Meyer, A.H.; Smith, P.P. What to do when we cant bank on seeds: What botanic gardens can learn from the zoo community about conserving plants in living collections. Am. J. Bot. 2016, 103, 1541-1543. [CrossRef]

23. Wood, J.; Ballou, J.D.; Callicrate, T.; Fant, J.B.; Griffith, M.P.; Kramer, A.T.; Lacy, R.C.; Meyer, A.; Sullivan, S.; Traylor-Holzer, K.; et al. Applying the zoo model to conservation of threatened exceptional plant species. Conserv. Biol. 2020, 34, 1416-1425. [CrossRef] [PubMed]

24. Tallamy, D.W.; Shropshire, K.J. Ranking Lepidopteran use of native versus introduced plants. Conserv. Biol. 2009, 23, 941-947. [CrossRef]

25. Varela, M.C.; Eriksson, G. Multipurpose gene conservation in Quercus suber-A Portuguese example. Silvae Genet. 1995, 44, 28-36.

26. Leroy, T.; Plomion, C.; Kremer, A. Oak symbolism in the light of genomics. New Phytol. 2019, 226, 1012-1017. [CrossRef] [PubMed]

27. Beckman, E. Conservation Gap Analysis of Native US Oaks; Morton Arboretum: Lisle, IL, USA, 2019.

28. McShea, W.J.; Healy, W.M.; Devers, P.; Fearer, T.; Koch, F.H.; Stauffer, D.; Waldon, J. Forestry matters: Decline of oaks will impact wildlife in hardwood forests. J. Wildl. Manag. 2007, 71, 1717-1728. [CrossRef]

29. Cavender-Bares, J. Diversity, distribution and ecosystem services of the North American oaks. Int. Oaks 2016, $27,37-48$.

30. Logan, W.B. Oak: Frame of Civilization; W.W. Norton \& Company, Inc.: New York, NY, USA, 2005.

31. Cavender-Bares, J. Diversification, adaptation, and community assembly of the American oaks (Quercus), a model clade for integrating ecology and evolution. New Phytol. 2019, 221, 669-692. [CrossRef]

32. Leroy, T.; Louvet, J.; Lalanne, C.; Le Provost, G.; Labadie, K.; Aury, J.; Delzon, S.; Plomion, C.; Kremer, A. Adaptive introgression as a driver of local adaptation to climate in European white oaks. New Phytol. 2020, 226, 1171-1182. [CrossRef]

33. Synge, H. The Biological Aspects of Rare Plant Conservation Edited by Hugh Synge, Seven forms of rarity; John Wiley \& Sons Ltd.: New York, NY, USA, 1981; pp. 205-217.

34. Beckman, E.; Hoban, S.; Spence, E.; Meyer, A.; Westwood, M. Species Profile: Quercus boyntonii Beadle; Conservation Gap Analysis of Native U.S: Thousand Oaks, CA, USA, 2019; pp. 74-79.

35. Toppila, R. Ex Situ Conservation of Oak (Quercus L.) in Botanic Gardens: A North American Perspective. Ph.D. Thesis, University of Delewarw, Newark, DE, USA, 2012.

36. Chabane, K.; Ablett, G.A.; Cordeiro, G.M.; Valkoun, J.; Henry, R.J. EST versus genomic derived microsatellite markers for genotyping wild and cultivated barley. Genet. Resour. Crop. Evol. 2005, 52, 903-909. [CrossRef]

37. Lobdell, M.S.; Thompson, P.G. Ex-situ Conservation of Quercus Oglethorpensis in Living Collections of Arboreta and Botanical Gardens. In Gene Conservation of Tree Species-Banking on the Future. Proceedings of a Workshop; Sniezko, R.A., Man, G., Hipkins, V., Woeste, K., Gwaze, D., Kliejunas, J.T., McTeague, B.A., Eds.; Tech. Cords. Gen. Tech. Rep. PNW-GTR-963; Department of Agriculture, Forest Service Pacific Northwest Research Station: Portland, OR, USA, 2017; Volume 963, pp. 144-153.

38. Kamvar, Z.N.; Tabima, J.F.; Grünwald, N.J. Poppr: An R package for genetic analysis of populations with clonal, partially clonal, and/or sexual reproduction. PeerJ 2014, 2, e281. [CrossRef]

39. Goudet, J. Hierfstat, a package for $\mathrm{r}$ to compute and test hierarchical F-statistics. Mol. Ecol. Notes 2005, 5, 184-186. [CrossRef]

40. Keenan, K.; McGinnity, P.; Cross, T.F.; Crozier, W.W.; Prodöhl, P.A. diveRsity: An R package for the estimation and explo-ration of population genetics parameters and their associated errors. Methods Ecol. Evol. 2013, 4, 782-788. [CrossRef]

41. Kraemer, P.; Gerlach, G. Demerelate: Calculating interindividual relatedness for kinship analysis based on codominant diploid genetic markers using R. Mol. Ecol. Resour. 2017, 17, 1371-1377. [CrossRef]

42. Blouin, M.S.; Parsons, M.; Lacaille, V.; Lotz, S. Use of microsatellite loci to classify individuals by relatedness. Mol. Ecol. 1996, 5, 393-401. [CrossRef] [PubMed]

43. Ritland, K. Estimators for pairwise relatedness and individual inbreeding coefficients. Genet. Res. 1996, 67, 175-185. [CrossRef]

44. Wang, J. An estimator for pairwise relatedness using molecular markers. Genetics 2002, 160, 1203-1215. [CrossRef] [PubMed]

45. Piry, S.; Luikart, G.; Cornuet, J.-M. Bottleneck: A program for detecting recent effective population size reductions from allele data frequencies. J. Hered. 1999, 90, 502-503. [CrossRef]

46. Fick, S.E.; Hijmans, R.J. WorldClim 2: New 1-km spatial resolution climate surfaces for global land areas. Int. J. Climatol. 2017, 37, 4302-4315. [CrossRef]

47. R Core Team. R: A Language and Environment for Statistical Computing; R Core Team: Vienna, Austria, 2020.

48. Petit, R.J.; Hampe, A. Some Evolutionary Consequences of Being a Tree. Annu. Rev. Ecol. Evol. Syst. 2006, 37, 187-214. [CrossRef]

49. Wojacki, J.; Eusemann, P.; Ahnert, D.; Pakull, B.; Liesebach, H. Genetic diversity in seeds produced in artificial Douglas-fir (Pseudotsuga menziesii) stands of different size. For. Ecol. Manag. 2019, 438, 18-24. [CrossRef] 
50. Marshall, D.R.; Brown, A.H.D. Optimum Sampling Strategies in Genetic Conservation. In Crop Genetic Resources for Today and Tomorrow. Cambridge University Press: Cambridge, UK, 1975; pp. 53-80.

51. Hoban, S.; Strand, A. Ex situ seed collections will benefit from considering spatial sampling design and species' reproductive biology. Biol. Conserv. 2015, 187, 182-191. [CrossRef]

52. Backs, J.R.; Terry, M.; Ashley, M.V. Using genetic analysis to evaluate hybridization as a conservation concern for the threatened species Quercus hinckleyi C.H. Muller (Fagaceae). Int. J. Plant Sci. 2016, 177, 122-131. [CrossRef]

53. Ashley, M.V.; Backs, J.R.; Kindsvater, L.; Abraham, S.T. Genetic variation and structure in an endemic island oak, Quercus tomentella, and mainland Canyon oak, Quercus chrysolepis. Int. J. Plant Sci. 2018, 179, 151-161. [CrossRef]

54. Hoban, S.M.; Gaggiotti, O.E.; Bertorelle, G. The number of markers and samples needed for detecting bottlenecks under realistic scenarios, with and without recovery: A simulation-based study. Mol. Ecol. 2013, 22, 3444-3450. [CrossRef] [PubMed]

55. Hoban, S.M.; Borkowski, D.S.; Brosi, S.L.; McCLEARY, T.S.; Thompson, L.M.; McLACHLAN, J.S.; Pereira, M.A.; Schlarbaum, S.E.; Romero-Severson, J. Range-wide distribution of genetic diversity in the North American tree Juglans cinerea: A prod-uct of range shifts, not ecological marginality or recent population decline. Mol. Ecol. 2010, 19, 4876-4891. [CrossRef]

56. Schnabel, A.; Hamrick, J.L. Comparative Analysis of Population Genetic Structure in Quercus macrocarpa and Q. gambelii (Fagaceae). Syst. Bot. 1990, 15, 240. [CrossRef]

57. Franklin, I.R.; Frankham, R. How large must populations be to retain evolutionary potential? Anim. Conserv. 1998, 1, 69-70. [CrossRef]

58. Hastings, K.; Frissell, C.A.; Allendorf, F.W. Naturally isolated coastal cutthroat trout populations provide empirical support for the 50/500 rule. In Proceedings of the 2005 Coastal Cutthroat Trout Symposium, Port Townsend, Washington, DC, USA, 29 September-1 October 2005; p. 121.

59. Stein, J.D. Field Guide to Native Oak Species of Eastern North America; U.S. Forest Service, Forest Health Technology Enterprise Team: Morgantown, WV, USA, 2001.

60. Koenig, W.D.; Ashley, M.V. Is pollen limited? The answer is blowin' in the wind. Trends Ecol. Evol. 2003, 18, 157-159. [CrossRef]

61. Ortego, J.; Riordan, E.C.; Gugger, P.F.; Sork, V.L. Influence of environmental heterogeneity on genetic diversity and structure in an endemic southern Californian oak. Mol. Ecol. 2012, 21, 3210-3223. [CrossRef]

62. Lira-Noriega, A.; Manthey, J.D. Relationship of genetic diversity and niche centrality: A survey and analysis. Evolution 2014, 68, 1082-1093. [CrossRef]

63. Diniz-Filho, J.A.F.; Rodrigues, H.; Telles, M.P.D.C.; De Oliveira, G.; Terribile, L.C.; Soares, T.N.; Nabout, J.C. Correlation between genetic diversity and environmental suitability: Taking uncertainty from ecological niche models into account. Mol. Ecol. Resour. 2015, 15, 1059-1066. [CrossRef]

64. Christe, C.; Kozlowski, G.; Frey, D.; Fazan, L.; Bétrisey, S.; Pirintsos, S.; Gratzfeld, J.; Naciri, Y. Do living ex situ collections capture the genetic variation of wild populations? A molecular analysis of two relict tree species, Zelkova abelica and Zelkova carpinifolia. Biodivers. Conserv. 2014, 23, 2945-2959. [CrossRef]

65. Sharrock, S.; Oldfield, S.; Wilson, O. Plant Conservation Report 2014: A Review of Progress towards the Global Strategy for Plant Conservation 2011-2020. CBD Technical Series; Convention on Biological Diversity: Montreal, QC, Canada, 2014.

66. Hurka, H. Conservation Genetics and the Role of Botanical Gardens. In Conservation Genetics; Loeschcke, V., Jain, S.K., Tomiuk, J., Eds.; Birkhäuser Basel: Basel, Switzerland, 1994; pp. 371-380. ISBN 9783034885102.

67. Maunder, M.; Higgens, S.; Culham, A. The effectiveness of botanic garden collections in supporting plant conservation: A European case study. Biodivers. Conserv. 2001, 10, 383-401. [CrossRef]

68. Griffith, M.P.; Calonje, M.; Meerow, A.W.; Tut, F.; Kramer, A.T.; Hird, A.; Magellan, T.M.; Husby, C.E. Can a botanic garden Cycad collection capture the genetic diversity in a wild population? Int. J. Plant Sci. 2015, 176, 1-10. [CrossRef]

69. Sharrock, S.; Jones, M. Saving Europe's threatened flora: Progress towards GSPC Target 8 in Europe. Biodivers. Conserv. 2010, 20, 325-333. [CrossRef]

70. Hoban, S.; Volk, G.; Routson, K.J.; Walters, C.; Richards, C. Sampling Wild Species to Conserve Genetic Diversity. In North American Crop Wild Relatives; Springer: Berlin/Heidelberg, Germany, 2018; pp. 209-228.

71. Hodel, R.G.J.; Segovia-Salcedo, M.C.; Landis, J.B.; Crowl, A.A.; Sun, M.; Liu, X.; Gitzendanner, M.A.; Douglas, N.A.; GermainAubrey, C.C.; Chen, S.; et al. The Report of my death was an exaggeration: A review for researchers using microsatellites in the 21st century. Appl. Plant Sci. 2016, 4, 1600025. [CrossRef]

72. Angeloni, F.; Wagemaker, N.; Vergeer, P.; Ouborg, J. Genomic toolboxes for conservation biologists. Evol. Appl. 2011, 5, 130-143. [CrossRef]

73. Petit, R.J.; Bodénès, C.; Ducousso, A.; Roussel, G.; Kremer, A. Hybridization as a mechanism of invasion in oaks. New Phytol. 2004, 161, 151-164. [CrossRef]

74. Petit, R.J.; Latouche-Hallé, C.; Pemonge, M.-H.; Kremer, A. Chloroplast DNA variation of oaks in France and the influence of forest fragmentation on genetic diversity. For. Ecol. Manag. 2002, 156, 115-129. [CrossRef]

75. Harada, K.; Dwiyanti, F.; Liu, H.-Z.; Takeichi, Y.; Nakatani, N.; Kamiya, K. Genetic variation and structure of Ubame oak, Quercus phillyraeoides, in Japan revealed by chloroplast DNA and nuclear microsatellite markers. Genes Genet. Syst. 2018, 93, 37-50. [CrossRef]

76. Borkowski, D.S.; Hoban, S.M.; Chatwin, W.; Romero-Severson, J. Rangewide population differentiation and population substructure in Quercus rubra L. Tree Genet. Genomes 2017, 13, 67. [CrossRef] 
77. Backs, J.R.; Ashley, M.V. Evolutionary history and gene flow of an endemic island oak: Quercus pacifica. Am. J. Bot. 2016, 103, 2115-2125. [CrossRef] [PubMed]

78. Ashley, M.V.; Abraham, S.T.; Backs, J.R.; Koenig, W.D. Landscape genetics and population structure in Valley Oak (Quercus lobata Née). Am. J. Bot. 2015, 102, 2124-2131. [CrossRef] [PubMed]

79. Craft, K.J.; Ashley, M.V. Landscape genetic structure of bur oak (Quercus macrocarpa) savannas in Illinois. For. Ecol. Manag. 2007, 239, 13-20. [CrossRef]

80. Dow, B.D.; Ashley, M.V. Microsatellite analysis of seed dispersal and parentage of saplings in bur oak, Quercus macrocarpa. Mol. Ecol. 1996, 5, 615-627. [CrossRef] 